\title{
37 手術室の清浄環境評価における簡易細菌サンプラーと微粒子測定の検討
}

富田敏司, 増田行雄, 中谷 博, 中田精三, 竹内秀子, 池田卓也（大阪大病院中央手術部）

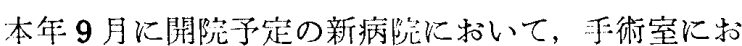
ける感染防止対策として高レベルなものが要求ざれ る.

これまで，手術環境の掯浄度の判定に，空氛中の細 菌数に代わる簡便な指標として，空父中の微粒子数を 測定してきたが，今後も新手術窒汇扔いて，清浄環境 に対する人と空調の影響を評価する為に，簡易サンプ ラーに上る空気中浮遊細菌数と空気中浮遊微粒子数と の相関について検討したので報告する。

対象として，HEPAフィルタ一使用の在来型乱流式 空調の同一手術室で，術前準備〜手術〜終了までの測 定を細菌数は 2 時間ごと，微粒子数は一定時間間隔で 連続して測定した。

細菌数の測定は, 細菌測定器 AIR TRENDTM (ク ラレ社製）を使用した．手術台の頭部付近の左右 1 籄 所ずつ，床上 $110 \mathrm{~cm}$ の高さに設谓して，2 $\mathrm{ft}^{3} / 10$ 分 の吸引量でサンプルを採取し，一般細菌用の液体培地 を注入後, ふ卵器内で $37^{\circ} \mathrm{C} 48$ 時間培養を行い, 発
奞したコロニ一数を， $1 \mathrm{ft}^{3}$ 当りの平均細菌数として算 出した。微粒子数の測定は The Portable ROYCO 社製）を使用し，頭部後方， 2 台の細菌測定 器の中央の床上 $110 \mathrm{~cm}$ の高さに微䊉子計のインレッ トを設置した。そして，米国航空宇宙局規格 (NASA) に準じて $0.5 \mu \mathrm{m}$ 以上及び $5 \mu \mathrm{m}$ 以上の粒径につい て測定した.

その結果, (1)細菌数, 微粒子数は人数や動作量に上る 污染度の美がみられた。 (2)手術中の微粒子数は $0.5 \mu \mathrm{m}$ 以上は 10 万值 $/ \mathrm{ft}^{3}$ 以下を維持したが， $5 \mu \mathrm{m}$ 以上は 700 個 $/ \mathrm{ft}^{3}$ を越える場合があった（3)微粒子の粒径が大き い汪ど, 細菌数との相関性が高い傾向がみられた.

$5 \mu \mathrm{m}$ 以上の微粒子数が多かったのは, 従来からの 测定結果からみて，衣服（綿製）の影響が大きいと考 えられる.細菌数と微粒子数の相関については異なっ た意見があるが，日常の手術環境の管理には，適切に 条件を選んで，微粒子数測定と簡易サンプラーを用い た細菌数测定の併用が害用的であろう。

\section{8 手術下着の素材変化による不織布ガウン内気候の比較検討 一高次複重層糸 PRH 50 を使用して一}

\author{
土井英史，高橋陽一，岡伊津穂 (府中病院手術室), \\ 土田和義, 石飛誠次 (東洋紡績), 角山 毦（住商衣料）
}

[目的] 不織布ガウンは, フィット感, 色彩, 機能 的デザインなどの課題は残されているものの，着用快 適性は素材の開発などにより従来より向上したと思わ れる。しかし，それにも関わらずガウン内気候のムレ 感，暑熱感に疑問を持つものも少なくない，そこで今 回不織布ガウンの素材ではなく，乎術下着の素材に着 眼し，ガウン内気候を快適域に保持できないか，手術 下着を従来のものと新素材である高次複重層系 PRH 50 を用い，手術中のガウン内温・湿度を測定し 比較 検討したので報告する.

[方法]任意に決めた不織布ガウンを使用し，手術 下着の素材を綿 100\%のもの，綿 65\% ポリエステル $35 \%$ のも，そして今回新素材として高次複重層禾 PRH 50 （マナール:最内層の疎水性繊維, 中間層の 親水性繊維と柾水性繊維の混合, 最外層の親水性緘維 よりなる 3 層構造）のものの 3 種類の素材を使用 し た. そして，ガウン内気候を温・湿度センサー（神栄
製平型THP-13）を用い，手術開始より終了まで連続 測定を行い素材变化による温・湿度の変化を比較検討 した.

〔結果〕従来より多くの施設で使用している手術下 着の綿 100\%の素材, 綿 65\% ポリエステル 35\% の素 材に比べて, 高次複重層系 PRH 50 を使用した手術 下着を着用したものは，他のものに比べてガウン内の 温・湿度は衣服内気候の快適域に保たれていた。

[考察]高次複重層系 PRH 50 を使用した手術下 着は，不織布ガウン内気候を快適に保ち，従来より使 用している綿 100\%の素材，綿 65\% ポリエステル 35 \%の素材に比べて，ガウン内気候に着眼すると有用 であると考える．今回のように手術下着の素材に着眼 し，新素材の高次複重層系 PHR 50 を使用すること は，従来の不織布午ウンの素材をより侍効に活用で き，ガウン内気候を考慮すると非常に有意義であると 考㝋る. 